\title{
Editorial
}

\section{The Special Issue: Problematising Assessment in Clinical Legal}

\section{Education}

Elaine Hall

Northumbria University, UK

Elaine.Hall@northumbria.ac.uk

On $4^{\text {th }}$ June 2015 Northumbria University hosted an interactive seminar and discussion forum, Problematising Assessment in Clinical Legal Education ${ }^{1}$, featuring Professor Judith McNamara (Queensland University of Technology), Professor Donald Nicholson (Strathclyde University), Professor Jose Garcia Anon (Valencia University), Richard Grimes (University of York), Cath Sylvester (Northumbria University) and Carol Boothby (Northumbria University). This seminar was supported by the Association of Law Teachers and their journal The Law Teacher as the recipient of their Seminar Prize.

The participants, representing legal educators from across the UK but also from Finland and Indonesia, explored the theme of how experiential learning in law is assessed. The international move towards an increasingly outcomes based approach to legal education and training has raised the profile and encouraged the development of a wide range of experiential learning practices in legal education. A

\footnotetext{
${ }^{1}$ https://www.northumbria.ac.uk/about-us/academic-departments/northumbria-law-school/lawresearch/legal-education-and-professional-skills/problematising-assessment-in-clinical-legal-education/
} 
key area of scrutiny for us at the IJCLE is the extent to which these practices evidence the multiple and complex competencies they lay claim to. The challenge of how to assess and what to assess in work integrated learning, problem and enquiry based learning, clinical legal education and simulated leaning is emerging as an important and developing issue and was eagerly and critically discussed by our speakers and participants, addressing the following key questions:

Why has experiential learning (and clinic in particular) historically been a voluntary element in legal education?

What are the implications of making CLE and experiential learning assessed options?

Where CLE is assessed, what is the nature and (implied) purpose of that assessment?

Can the reflective and experiential elements of CLE be codified into assessment rubrics that provide guidance to students without reducing their depth and complexity?

How is the clinical training and assessment of students linked to the wider discourse of what a lawyer is and can do?

The presenters all made use of the work on constructive alignment by Cees van der Vleuten $^{2}$ and we were delighted and honoured that he agreed to act as discussant for this special issue. The papers presented at the seminar were revised in the light of the discussion and challenge from the participants and then reviewed and responded to by Cees. His contribution takes us beyond the legal education context and into wider debates about education and professional competence.

\footnotetext{
${ }^{2}$ http://nrl.northumbria.ac.uk/21582/
} 
The papers represent honest and transparent reflections on the limitations and potential of current practice. There are strong pragmatic and ethical themes about the virtues of experiential learning and the ways in which such experiences can be assessed. In particular, the claim that experiential work and clinic in particular are more 'real': this is attractive but also perilous, for if the student must be real and seen in the whole then the stakes for assessment are very high indeed, as Cath Sylvester emphasises with her title: "For now we see through a glass, darkly; but then face to face: now I know in part; but then shall I know even as also I am known" (The Bible, 1 Corinthians 13:12, King James Version). The papers therefore represent the opening of a complex and fascinating discussion about assessment, to which I hope many of you will add your own contributions in future issues. 
Here is the reminder of upcoming events in the CLE world: there is still time to submit a proposal for two conferences.

Firstly, (1-3 APRIL 2016) our colleagues in South Africa host the Ed O'Brien International Street Law and Legal Literacy Best Practices Conference, which will honour our late colleague Ed O'Brien and celebrate the 30th Anniversary of the First International Street Law Programme established at the University of KwaZulu-Natal (formerly the University of Natal), South Africa. The conference will be preceded by a three day Ed O'Brien Memorial Safari (29-31 March 2016) to the world famous Hluhluwe-Imfolozi Game Reserve where the white rhinoceros was saved from extinction.

Secondly, the International Legal Ethics Conference VII (ILEC VII), which Fordham Law School will host in New York City on July 14-16, 2016 focusing on legal education, ethics, technology, regulation, globalization and rule of law (www.law.fordham.edu/ilec2016). This conference follows hot on the heels of The Risks and Rewards of Clinic, the IJCLE conference in partnership with the Association for Canadian Clinical Legal Education (ACCLE) Conference, hosted by the University of Toronto from 10-12 July. Submissions are now closed and we have a fantastic range of papers, seminars and symposia with Sarah Buhler and Adrian Evans as keynote speakers. Registration for this event is now open! https://www.eventbrite.com/e/the-risks-and-rewards-of-clinical-legal-education-programsa-joint-ijcle-accle-conference-registration-20017850931 